\title{
Employee's Emotions: A Manageable Weapon for Organizations
}

\author{
Irene Akuamoah Boateng \\ Department of Management Studies \\ Valley View University, Oyibi, Accra
}

\author{
Albert Agyei \\ School of Business, Valley View University, Oyibi, Accra \\ E-mail Address: agyeialbert74@gmail.com
}

Doi:10.5296/ijhrs.v3i4.4910

URL: http://dx.doi.org/10.5296/ijhrs.v3i4.4910

\begin{abstract}
Emotion in the workplace for many years was only considered important in relation to employee wellbeing and job satisfaction. In recent times, it has been recognized that emotions play a role in almost all work activities. Consequently, this research is to determine the relevance of managing employees emotions at the workplace. The study dealt with the identification of the causes of employee emotions, challenges faced by managers in regard to the management of employee's emotions and examined the measures used in managing employee emotions. Primary data was collected by administering questionnaire to employees and management of Valley View University. Sample size of fifty (50) employees and ten (10) management members were selected conveniently for the study. The study revealed that the main causes of employee emotion are, excessive workload, lack of guidance and support, meeting deadlines, role dissatisfaction and ambiguity of job description. Measures identified that are used in managing employee emotions are provision of counseling centre, organization of periodic seminars on how to deal with emotions and other work related issues, creation of harmonious relationship with employees and reduced work load. The challenges faced by managers with regard to the management of employee's emotions are miscommunication and inability of the employer in identifying the personal traits of the employee.
\end{abstract}

Key Words: Emotions, Emotional Labour, Emotions Management, Organisations, Employees.

\subsection{Introduction}

Emotion is one of the unique qualities that make us human. Emotion is used to create, monitor, and preserve social bonds. Emotion is also an important element in conflict, social movements, and social change (Hochschild, 1990). There is no well-accepted definition of the term "emotion". In line with the difficulty in defining "emotion", it has hampered research on it for a long time. Emotion management refers to the ways in which people 
influence their own feelings and expressions and the ways in which they influence other people's feelings. All employees engage in emotion management as part of their jobs and employers often play a significant role in shaping emotion management. In this complex situation, both public and private sector organizations have to manage emotions in an effective way in order to get the best out of their employees towards the achievement of organizational goals/objectives. Emotions when managed well keep employees healthy since experiencing emotions is part of being human.

Over the past few years, emotions in the workplace were only considered important in relation to employee wellbeing and job satisfaction. More recently, it has been recognized that emotions play a role in almost all work activities within an organization. Employment involving working with people entails learning to manage one's own emotions in order to continue to operate, also to arouse desirable responses in other people, (Hochschild, 1983).

Gross and Thompson (2007) highlight the important roles that emotions play as "they are ready necessary behavioral responses, tune our decision making, enhance memory for important events and facilitate interpersonal interactions."

Managing emotions plays a critical role in helping managers and employees to cope with the dynamic changes in the business environment. Managing emotions also supports the managers and employees to recognize and understand emotions and use emotional intelligence to manage oneself and his or her relationship with others (Wall, 2008).

In this light, organizations must coach their employees in developing their interpersonal skills and train them to perform effectively on the job with other employees in the organization. Negative consequences arise if employees are encouraged to suppress their emotions or allowed to have outbursts and treat their co-workers poorly. The work environment could potentially become hostile, resulting in high turnover rate, sub-par performances, and low morale, which ultimately affects the organization (Hochschild, 1983).

In order for organizations to be successful in overcoming such circumstances, it needs to develop employee's emotional intelligence skills to work effectively and efficiently in the organization (Miller 1994). Since employees are one of the tangible assets of an organization, the concept of employee emotions must not be taken for granted because employees define organizations. It is therefore against this background that the researchers conducted this study to assess employee emotions to identify the causes, measures used by management and challenges faced by organizations in dealing with employees of emotions.

The specific objectives of the study are;

- To determine the major causes of employee emotions in the workplace,

- To identify the major measures used by management in handling employee emotions in the workplace and

- To examine the key challenges faced by management in regard to the management of employees' emotions. 


\subsection{The Theory of Emotions}

Emotions are feelings that people experience, interpret, reflect on, express, and manage (Thoits, 1989; cited in Chu, 2002). Emotion can also be defined as a complex state of feelings that brings out physical and psychological changes that influence thought and behavior (Cherry, n.d). She continued to say that emotionality is associated with psychological phenomena including temperament, personality, mood and motivation.

Again, Fischer, Shaver and Carnochan (1990) describe emotion as a "discrete, innate, functional, biosocial action and expression system." Mathur, Nathani and Sarvate (2013) claim that it is really difficult to identify one's emotion even though there are methods of showing what is going in one's mind. They suggest that even though emotion is difficult to determine, its role of at work cannot be undermined. According to Martins (1999 cited in Chu, 2002) emotions arise through social interaction, and are influenced by social, cultural, interpersonal, and situational conditions.

In this regard, there are times people find themselves suppressing their feelings in order to display a behavior that will be socially acceptable and appropriate (Chu, 2002). Controlling emotions in order to conform to occupational norms or demands of the job is what Hochschild, (1990; p. 118) termed as "emotional labor."

Emotional labor is therefore defined by Hochschild as the controlling of feeling to create an outwardly observable facial and bodily display. Here, she says emotion is sold for a wage and therefore has an exchange value (Hochschild, 1983; p.7). Chu (2002) also defines emotional labor as control of a person's behavior to display acceptable behavior.

According to Mathur, Nathani and Sarvate (2013), the implication of this is that, a person expresses certain kinds of emotions which are socially expected as well as accepted; hence they consider these as not real feelings because the person is actually supposed to hide emotions which are not conforming to social standards. The impulse of their assertion is that, once someone is forced or coerced into hiding the true and real feelings, it ceases to be called emotions. With this in mind, can it therefore be proper for organizations to allow their employees to express whatever emotions they feel outwardly without any constraints?

The answer to this question is given by Labroo and Mukhopadhyay (2009: pp 242-243) as "when faced with a choice that enables people to regulate their immediate effect, they will behave in a way that accomplishes their immediate affect-regulation objectives, but only when they believe that such a behavior is necessary. When immediate affect regulation is attained without any action, people will forgo behaviors that have immediate consequences for their feelings and make decisions that have long-term benefits." It is against this background that managers of organizations do their best to make employees control their emotions to suit their job demands in order to help the organization achieve its set objectives. 
Organizations must know how to manage emotions of employees very well in order not to also suppress the feelings of employees to much. When suppression continues for a long time, the employee may boil out or explode with emotions that may be damaging to the organization and other co-workers of that individual.

According to Toegel, Kilduff and Anand (2013) some of the sources of negative workplace emotions are going through a promotion, massive client work, job-related anxieties concerning deadlines, not meeting monthly targets, change of work roles, and difficult direct reports. Further, Rafaeli, Semmer and Tschan (n.d) posit that " negative emotions appear to be experienced in a more differentiated way than positive ones, and are typically triggered by communication that is ineffective (e.g., failing to inform) or inappropriate (yelling, blaming), by lack of awareness and respect, and by lack of empowerment.” (p5)

\subsection{Managing Emotions in Organizations}

The idea of managing emotions has been expressed by different researchers from different point of view. Some think that it should be left with the employees to manage whiles others also think management should be involved in the management of emotions. In this regard, many organizations train their workforce in managing their emotions. Morris and Feldman (1997 cited in Mathur, Nathani and Sarvate, 2013) suggested that to utilize emotional labour effectively in an organization, employees must be selected on the basis of their expressive style and the display norms likely to be encountered in the job. But the problem with their approach is that, can organizations actually use only the recruitment process to select employees who best exhibit or display emotions that suit the organization style? Since it is difficult for organizations to use this approach in managing the emotions, a much broader approach must be used in the recruitment and selection process. It must however be noted that applicants or interviewees may hide their true characters in order to gain the employment that they seek for.

Again, Toegel, Kilduff and Anand (2013) raised another interesting area of concern. They argue that while critical theorists like Bolton argue that private aspects of life such as emotions should not be subsumed under the managerial gaze, social exchange researchers like Blau, Lawler and Thye, are of the view that the provision of emotion help is part of an exchange arrangement by which employees reciprocate increased commitment, performance, or personal favors. They argue that although the importance of social exchange in the context of emotion help in other forms of prosocial and organizational citizenship behaviors (OCBs) between managers and subordinates is well established questions concerning why and how managers engage in the process of helping subordinates with their negative emotions remain to be answered.

According to Mayer and Salovey (1997), managing emotions requires the following abilities: being equally open to pleasant and unpleasant emotions; deliberate engagement with or detachment from a specific emotion, conscious monitoring of emotions towards oneself and 
the others; the ability to manage emotions by making negative emotions weaker and intensifying positive ones.

Seo and Barrett (2007 cited in Mirela, and Lulia, 2013) suggested alternative approach organizations could adopt towards feelings. To them, these are fostering the freedom of managers/employees to experience and express their emotions to maximize the positive outcomes of those feelings, while simultaneously helping them minimize the emotions' potential negative impacts.

Huy (2011) suggests that managers can increase their emotional self awareness by acquiring a richer meaning of emotions, by understanding the causes and consequences of various emotions such as shame, guilt, anger, pride and joy so they can recognize and regulate them, and express them to others in a well articulated way.

\subsection{Methodology}

The research was basically a descriptive research, which involves the collection of extensive narrative data. The population of the study comprised employees and management of Valley View University. The sampling technique that was employed by the researchers is non-probability sampling. Thus convenience sampling technique was used to conduct this study; primarily respondents who were available and willing to answer the questionnaires were used.

The sampling size comprised of ten (10) management members and sixty (60) employees. The study relied on primary data as it source of data. The primary data was obtained from the respondents through a carefully constructed questionnaire. Questionnaires are often used as part of a survey strategy to collect descriptive and explanatory data about attitudes, beliefs, behaviours and attributes (Buame, 2006 cited in Akafo, 2012). Questionnaire was used since it was cheaper and guaranteed anonymity. Items on the questionnaire sought respondents' views on objectives of the study. The questionnaire was designed to capture the demographic data of respondents and their opinion with respect to the research questions. The questionnaire was divided into four sections.

Section A collected data about the demography of the respondents. The section B collected data about the causes of employees' emotions in the work place which were responded to by employees. The section $\mathrm{C}$ also collected data about the ways management use in managing employees' emotions and the section D was used to collect data about the challenges management face in dealing with emotions of employees.

The questions were all closed ended. The questions were designed based on the five point Likert scale. The questionnaires were personally administered to the respondents. The respondents were required to indicate extent of their agreement or disagreement with each of the statements on a score of one (1) to five (5). A score of one (1) represented strong 
disagreement with the statement, while a score of five (5) represented strong agreements. This type of scaling was suggested when items are to be judged on a single dimension and arrayed on a scale with equal interval (Alreck \& Settle, 1995). Data collected were analysed through descriptive statistics.

They were analysed through frequency distribution tables. The data were later ranked through mean scores (represented by response average) for the respective responses. Responses with the response average of 4.0 and above were used for the discussion. The data were analysed with the help of Statistical Package for Social Sciences, (SPSS Version 14.0).

\subsection{Discussion of Findings}

Fifty (50) questionnaires were returned by the employees and used in the analysis and ten were also returned by management and used in the analysis. In all sixty (60) respondents were used in the study. The gender of the respondents consisted $60 \%$ males and $40 \%$ females. The age groups of the respondents were; $65.8 \%$ were between $18-28$ years, $15.8 \%$ were between 29-39 years, $15.8 \%$ were between $40-50$ years and only $2.6 \%$ were between $51-60$ years.

\section{Tab. 1 Causes of Employee Emotion}

\begin{tabular}{|c|c|c|c|c|c|c|}
\hline Causes of Emotions & $\begin{array}{l}\text { Strongly } \\
\text { Disagree }\end{array}$ & Disagree & Neutral & Agree & $\begin{array}{l}\text { Strongly } \\
\text { Agree }\end{array}$ & $\begin{array}{l}\text { Response } \\
\text { Average }\end{array}$ \\
\hline Meeting Deadlines & $2.5 \%$ & $5.0 \%$ & $12.5 \%$ & $45.0 \%$ & $35 \%$ & 4.05 \\
\hline Excessive workload & $0 \%$ & $5.0 \%$ & $5.0 \%$ & $57.5 \%$ & $32.5 \%$ & 4.18 \\
\hline $\begin{array}{l}\text { Lack of Guidance } \\
\text { and Support }\end{array}$ & $0 \%$ & $7.5 \%$ & $15.0 \%$ & $37.5 \%$ & $40 \%$ & 4.10 \\
\hline $\begin{array}{l}\text { Unfair treatment by } \\
\text { managers }\end{array}$ & $0 \%$ & $10.0 \%$ & $17.5 \%$ & $42.5 \%$ & $30.0 \%$ & 3.93 \\
\hline $\begin{array}{l}\text { Quarrels with } \\
\text { co-workers }\end{array}$ & $2.5 \%$ & $7.5 \%$ & $22.5 \%$ & $42.5 \%$ & $25.0 \%$ & 3.80 \\
\hline Role dissatisfaction & $0 \%$ & $2.5 \%$ & $17.5 \%$ & $52.5 \%$ & $27.5 \%$ & 4.05 \\
\hline Verbal abuse & $0 \%$ & $10.0 \%$ & $17.5 \%$ & $47.5 \%$ & $25.0 \%$ & 3.88 \\
\hline $\begin{array}{l}\text { Conflict arising from } \\
\text { work in diversity } \\
\text { team }\end{array}$ & $0 \%$ & $7.5 \%$ & $15.0 \%$ & $50.0 \%$ & $27.5 \%$ & 3.98 \\
\hline $\begin{array}{l}\text { Ambiguity of job } \\
\text { description }\end{array}$ & $0 \%$ & $2.5 \%$ & $10.0 \%$ & $67.5 \%$ & $20.0 \%$ & 4.03 \\
\hline
\end{tabular}


Lack of rewards

$0 \%$

$10.0 \%$

$22.5 \%$

$32.5 \%$

$35.0 \%$

3.93

Emotions can be positive or negative. The researchers only considered the causes that bring about negative emotions. The study revealed that among the factors that cause emotions among employees of Valley View University, excessive workload was adjudged the highest factor with response average of 4.18. The second highest factor that causes emotion among the employees was lack of guidance and support relating to work with response average of 4.10. Meeting deadlines and role dissatisfaction came next as factors that cause employee emotions with each having response average of 4.05 each. Again, ambiguity of job description was seen as the last factor that causes emotions among employees.

Tab. 1 shows that higher percentages were recorded for both Strongly Agree and Agree relating to almost all the factors that were considered by the researchers as causes of employee emotions at the work place. Therefore, in other to get the main causes of employee emotions, the researchers used the average responses.

Previous researches concerning causes of employees' emotions at the workplace such as Toegel, Kilduff and Anand (2013) and Rafaeli, Semmer and Tschan (n.d) touched on just the causes. These studies did not rank the causes as to the ones employees consider the major. This study has gone further to look at the causes and its effect employees. This is the reason why the researchers used the average responses to come out with the most factors that causes emotions among employees.

In the study by Toegel, Kilduff and Anand (2013), they looked at causes of negative emotions from the angle of those that are work related and those that happened outside the work place. Negative emotions, whether carried over from home or emerging in the workplace, threaten productivity and can spread across the organization to affect other employees' cooperation and work performance.

The causes of emotions given by the employees of Valley View University such as excessive workload, meeting deadlines, role dissatisfaction, and ambiguity of job description were consistent with the findings of Toegel, Kilduff and Anand (2013) and Rafaeli, Semmer and Tschan (n.d) 
Tab. 2 Measures used in managing employee's emotions

\begin{tabular}{|c|c|c|c|c|c|c|}
\hline Measures & $\begin{array}{l}\text { Strongly } \\
\text { Disagree }\end{array}$ & Disagree & Neutral & Agree & $\begin{array}{l}\text { Strongly } \\
\text { Agree }\end{array}$ & $\begin{array}{c}\text { Response } \\
\text { Average }\end{array}$ \\
\hline Reduced work load & $0.0 \%$ & $7.5 \%$ & $15.0 \%$ & $45.0 \%$ & $32.5 \%$ & 4.03 \\
\hline $\begin{array}{l}\text { Provision Counseling } \\
\text { Centre }\end{array}$ & $2.5 \%$ & $2.5 \%$ & $10.0 \%$ & $45 \%$ & $40 \%$ & 4.18 \\
\hline $\begin{array}{ll}\text { Easy accessibility to } \\
\text { management } \\
\text { employees }\end{array}$ & $12.5 \%$ & $5.0 \%$ & $17.5 \%$ & $40.0 \%$ & $25.0 \%$ & 3.60 \\
\hline $\begin{array}{l}\text { Manage } \\
\begin{array}{l}\text { employee } \\
\text { corums } \\
\text { concerns }\end{array}\end{array}$ & $7.5 \%$ & $5.0 \%$ & $30.0 \%$ & $42.5 \%$ & $15.0 \%$ & 3.53 \\
\hline $\begin{array}{lr}\text { Create } & \text { harmonious } \\
\text { relationship } & \text { with } \\
\text { employees } & \end{array}$ & $5.0 \%$ & $5.0 \%$ & $2.5 \%$ & $52.5 \%$ & $35.0 \%$ & 4.08 \\
\hline Relaxed work schedules & $7.5 \%$ & $15.0 \%$ & $10.0 \%$ & $40.0 \%$ & $27.5 \%$ & 3.65 \\
\hline $\begin{array}{l}\text { Organize periodic } \\
\text { seminars on how to deal } \\
\text { with emotions and other } \\
\text { work related issues }\end{array}$ & $0.0 \%$ & $5.0 \%$ & $10.0 \%$ & $55.5 \%$ & $30.0 \%$ & 4.10 \\
\hline
\end{tabular}

The researchers observed from Tab. 2 that a higher percentage was recorded for almost all the factors above as being the measures that can be used to control employee emotion at the workplace. As a result of this, the response average was used to determine the ways in which management control employees' emotion.

After using this criterion, the researchers found that the measures used by management were through provision of counseling centre with response average of 4.18. The second measure was through the organization of periodic seminars on dealing with emotions and other work related issues with average response rate of 4.10. Creation of harmonious relationship with employees and reduction of workload were the other measures used by management in dealing with employees' emotions at the workplace.

It is not surprising that majority of management members think that provision of counseling centre is the best way of managing employees' emotions at the workplace even though employees see excessive workload as the major cause of negative emotions. Management may be right in thinking that way because, among the challenges faced by them (in Tab.3 below) in dealing with emotions, inability to know the personality traits of the employees came up. This indicates that management may be applying the right emotion management method at the wrong time even though counseling is another way of managing emotions. The difficulty is that if employees are unable to tell the counselors about the actual causes of 
emotions, then it will be very difficult for management to know the right management technique.

Further, it is not surprising that management see reduction of workload as the least among the best emotions management methods or strategies to be applied. This is because the organization is there to make sure that its objectives are met of which the employees must work. It may be that management think by reducing the workload of employees, it may hinder the organizations' ability to achieve its objectives. Generally, supervisors usually do not consider reduction of workload of employees as the best option since organizational goals take precedence over every other activity.

These revelations indicate that, management cannot be blamed too much since managing emotions of another person is very difficult especially when it comes to workplace where much depend on the nature of work of the employee, it may be difficult to recognize the exact of emotions being experienced by the employee at a time.

Tab. 3 Challenges faced by managers with regard to the management of employee's emotions

\begin{tabular}{|l|c|c|c|c|c|c|}
\hline Challenges & $\begin{array}{l}\text { Strongly } \\
\text { Disagree }\end{array}$ & Disagree & Neutral & Agree & $\begin{array}{c}\text { Strongly } \\
\text { Agree }\end{array}$ & $\begin{array}{c}\text { Response } \\
\text { Average }\end{array}$ \\
\hline $\begin{array}{l}\text { Miscommunication } \\
\text { between manager and the } \\
\text { employee }\end{array}$ & $0 \%$ & $5.0 \%$ & $7.5 \%$ & $60.0 \%$ & $27.5 \%$ & $\mathbf{4 . 1 0}$ \\
\hline $\begin{array}{l}\text { Inability to know } \\
\text { personality traits }\end{array}$ & $0 \%$ & $2.5 \%$ & $10.0 \%$ & $62.5 \%$ & $25.0 \%$ & $\mathbf{4 . 1 0}$ \\
\hline $\begin{array}{l}\text { Inability to support } \\
\text { employees with emotional } \\
\text { difficulties. }\end{array}$ & $2.5 \%$ & $5.0 \%$ & $25.0 \%$ & $40.0 \%$ & $27.5 \%$ & 3.82 \\
\hline $\begin{array}{l}\text { Inability of employees to } \\
\text { express emotions well to } \\
\text { aid assistance }\end{array}$ & $2.5 \%$ & $5.0 \%$ & $10.0 \%$ & $60.0 \%$ & $22.5 \%$ & 3.95 \\
\hline $\begin{array}{l}\text { Communication gap } \\
\text { between managers and } \\
\text { employee }\end{array}$ & $2.5 \%$ & $7.5 \%$ & $20.0 \%$ & $40.0 \%$ & $30.0 \%$ & 3.88 \\
\hline $\begin{array}{l}\text { The ability to recognize } \\
\text { employee emotion by } \\
\text { manager }\end{array}$ & $0.0 \%$ & $5.0 \%$ & $17.5 \%$ & $62.5 \%$ & $15.0 \%$ & 3.88 \\
\hline
\end{tabular}

The study Tab. 3 above revealed that among the situations that poses challenges to management, miscommunication between management and employees, and inability of 
management to know the personality traits of the employees were the most pressing challenges with response average of 4.10 each.

Moreover, observation from the Tab. 3 confirms that most of the factors posed by the researchers had higher percentages for both strongly agree and agree. Therefore, for the researchers to come out with the most challenging factors, average response rating of 4.0 and above were set to determine the challenges. It is not surprising that among the challenges faced by management in dealing with employees' emotions, inability to know personal traits and miscommunication between managers and employees came up as the most challenging. Emotion is something that is felt by only the person or individual who experiences it. Therefore, unless it is exhibited by the person feeling it, either through facial expression, mood or acts by the individual, it will continue to become a challenge for management to pinpoint and manage the emotions well. This brings to fall why Morris and Feldman (1997 cited in Mathur, Nathani and Sarvate, 2013) suggested that employees must be selected on the basis of their expressive style and display norms likely to be encountered in the job.

Employees sometimes are unable to communicate their emotions well to their managers to enable help. Emotion, if not well communicated can be very difficult to diagnose since some employees are required by the nature of their work to suppress their feelings and 'surface act' as if all is well.

\subsection{Conclusion and Recommendations}

Emotion is part of every human being. Emotion cannot be ignored in human life since it is part of our daily lives. The emotions people feel at home is sometimes carried to the workplace or vice versa. Emotions, if not properly managed at the workplace could mar the operations of the organization. The researchers therefore conducted this study to assess employee emotions, causes, measures used by management and challenges faced by organizations in dealing with emotions of employees. We found that the main causes of employee emotion are, excessive workload, lack of guidance and support, meeting deadlines, role dissatisfaction and ambiguity of job description. We further found that measures identified that are used in managing employee emotions by management are provision of counseling centre, organization of periodic seminars on how to deal with emotions and other work related issues, creation of harmonious relationship with employees and reduced work load. The challenges faced by managers with regard to the management of employee's emotions are Miscommunication and inability of the management in identifying the personal traits of the employee.

The researchers recommend that even though employees should not be freely allowed to display their negative emotions like anger, sadness, anxiousness, etc, and must be controlled, the management must not over-suppress the emotions of the employees.

Again, management must know from the employees or use emotional intelligence to know the right strategy that will help manage negative emotions in order for employees to be satisfied while at the same time fulfilling organizational objectives. This will create a win-win situation.

Lastly, the researchers recommend further study to be conducted on how employees 
themselves are able to manage their emotions at the workplace. This is because emotions are better felt and managed by the person who is affected. A study can also be conducted to include larger sample and different organizations in order to aid generalization. Another study can be conducted to know how these causes of emotions can affect organizational performance in the educational environment.

\section{Acknowledgement}

We acknowledge Galley Raymond Prince for his contribution towards data collection for this study. May God richly bless him and open many doors of opportunities for him.

\section{REFERENCES}

- Alreck P.L. \& Settle R.B. (1995). The Survey Research Handbook. (2 ed.).Chicago: Richard D. Irwin Inc.

- Ashforth, B.E., \& Humphrey. R.H. (1995). Emotion in the workplace. A reappraisal. Human Relations, 48(2), 97-125.

- Cherry, K. (n.d). Theories of emotion. Available at http://psychology.about.com/od/psychologytopics/a/theories-of-emotion.htm

- $\mathrm{Chu}, \mathrm{K}$. H-L (2002). The effect of emotional labor on employees work outcome, Dissertation submitted to the Faculty of the Virginia Polytechnic Institute and State University. Available at http://scholar.lib.vt.edu/theses/available/etd-06302002-164031/unrestricted/Chuetd.pdf

- Fischer, K. W., Shaver, P. R., \& Carnochan, P. (1990). How emotions develop and how they organise development. Cognition and emotion, 4 (2), 81-127.

- Gross, J. \& Thompson, R. (2007). Emotion regulation: Conceptual foundations. In: J. Gross, (Ed). Handbook of Emotion Regulation. pp. 3-26. New York: Guilford Press.

- Hochschild, A.R. (1983). The managed heart: Commercialization of human feeling. Berkeley: University of California Press.

- Hochschild, A. R. (1990). Arlie Hochschild: The presentation of emotion. Available at http://www.sagepub.com/upmdata/13293_Chapter4_Web_Byte_Arlie_Russell_Hochschild.p df

- Huy, Q.N. (2011). How middle managers' goup-focus emotions and social identities influence strategy implementation. Strategic Management Journal, 32, 1387-1410.

- Labroo, A.A., \& Mukhopadhyay, A. (2009). Lay theories of emotion transience and the search for happiness: A fresh perspective on affect regulation. Journal of Consumer Research, Inc, 36, 242-254. DOI; 10.1086/597159 
- Lazányi, K. (n.d). Who benefits from emotional labour? Applied Studies in Agribusiness and Commerce-APSTRACT, 1-4. Available at http://ageconsearch.umn.edu/bitstream/94398/2/11_Lazanyi\%20Who_Apstract.pdf

- Mathur, G., Nathani, N., \& Sarvate, S. (2013). An emotional antecedent to stress at work in health care. Advances in Management \& Applied Economics, 3(1), 1-10

- Mayer, J.D. \& Salovey, P. (1997). What is emotional intelligence? In Salovey, P., Sluyter, D.J. (eds.) Emotional Development and Emotional Intelligence (pp. 332),

New York: Basic Books.

- Miller, P. M. (1994, June). Cultural and socioeconomic influences on mothers' touching in mother-infant interaction. Paper presented at the Ninth International Conference on InfantStudies, Paris, France.

- Mirela, P., \& Lulia, S.I. (2013). Emotions in the organizational environment. Annals of the University of Oradea, Economic Science Series. 1595-1605. Available at http://web.ebscohost.com/ehost/pdfviewer/pdfviewer?sid=0d5beeb6-263d-4b69-9595-45d55 $88 \mathrm{e} 1241 \% 40$ sessionmgr14\&vid=1\&hid=1

- Rafaeli, A., Semmer, N., \& Tschan, F. (n.d). Emotion in work settings. Oxford Companion to the Affective Sciences, 1-9. Available at http://ie.technion.ac.il/Home/Users/anatr/Rafaeli-Semmer-Tschan-Emotions-at-Work_Oxfo rdComp.pdf

- Toegel, G., Kilduff, M., \& Anand, N. (2013). Emotion helping by managers: An emergent understanding of discrepant Role expectations and outcomes. Academy of Management Journal, 56(2), 334-357. Available at http://dx.doi.org/10.5465/am;.2010.0512

- Wall, B. (2008). Working relationships using emotional intelligence to enhance your effectiveness with other ( $1^{\text {st }}$ ed.). USA: Davies Black Publishing. 